\title{
GROWTH AND ECONOMIC PERFORMANCE OF USING DRIED TOMATO POMACE FOR MALLARD DUCKS
}

\author{
Mohamed A. Omar', Tamer M. Abdel-hamid², Sara Esam³, Annam E. Omar \\ 1,3Veterinary Economics and Farm Management, Animal Wealth Development, Faculty of \\ Veterinary Medicine, Zagazig University. ${ }^{2}$ Animal Breeding and Production, Animal Wealth \\ Development, Faculty of Veterinary Medicine, Zagazig University. ${ }^{4}$ Animal Nutrition and Clinical \\ Nutrition Department, Faculty of Veterinary Medicine, Zagazig University.
}

*Corresponding author, E-mail: omarkafay@yahoo.com

\begin{abstract}
This study was aimed to economic evaluate the effect of Dried Tomato Pomace (DTP) on growth performance, biochemical profiles and economic efficiency of Mallard Ducks from 1 days old until 72 days (age of marketing). A total of 240 unsexed one - day old, Mallard ducklings were used in this study and were randomly and independently allocated to the four dietary treatments, each containing 60 ducks and divided in to four groups, T1 (control ), T2 ( $10 \%$ DTP), T3 (15\% DTP) and T4 (20\% DTP). The diets were formulated in mash form fortified with vitamin and mineral premix and chemical analysis were applied for starter and finisher rations. Moreover, feed and water were provided for ad-libitum consumption. The results showed that, ducks fed $20 \%$ DTP had higher live body weight with a coincident significant increase of the feed intake $(P<0.05)$. In addition, total cholesterol, Triglycerides, high density lipoprotein (HDL) are decreased significantly $(P<0.05)$ meanwhile low density lipoprotein $(L D L)$, total protein profiles non-significant $(P$ $>0.05$ ). In terms of economic analysis, T4 (20\% DTP) diet revealed the lowest cost per $\mathrm{Kg}$ live weight of ducks 77.57 L.E / duck, along with the highest economic return 91.38 L.E per duck and net profit 13.81 L.E per duck. In conclusion, Mallard duck can efficiently utilize diet containing high DTP $(20 \%)$ diets, consequently, it can be used to optimize their growth performance and maintain the maximum economic return.
\end{abstract}

Key words: Mallard duck; dried tomato pomace; growth performance; economics efficiency

\section{Introduction}

The poultry sector is considered the fast growing and flexible of all live stock sectors and Egyptian poultry industry has improved and become occupied a place of glory among the livestock enterprises as it is providing a great part of increasing demand for animal protein. Moreover, it is characterized by rapid monetary turnover, short production cycle and higher return on investment (1). The feed plays remarkable role in poultry production by sharing about $70 \%$ of total production costs. So, great efforts have been made to improve feed utilization and conversion to meat to minimize the feeding cost by feeding a well-balanced diet and supplementing diet with various feed additives $(2,3)$.

Tomato (Lycopersicon esculentum) is one of the most popular vegetables used as salad in 
food preparation and as juice, soup, ketchup or paste. Commercial processing of tomato produce large amount of waste at various stages. Tomato pomace (TP) is mixture of tomato skin, pulp and crushed seed that remain after the processing of tomato for juice, paste and ketchup (4). From $1000 \mathrm{~kg}$ of fresh tomatoes, 100 to 300 $\mathrm{kg}$ wet tomato pulp are produced and normally disposed of being sold as animal feedstuffs (5), and its nutritional value is highly dependent on the tomato cultivars, growing conditions, degree of drying and processing method (6).

Some by-products originated from food industry processing are utilized in animal feeding. However, the utilization of certain products is not generally applied in animal nutrition. One of these by-products is the peels and seeds of tomato called in common (tomato pomace) remaining usually from the processing of tomato. In Egypt, about 550.000 to 660.000 tons of tomato by-products are yearly produced from canning industry. Unfortunately, a great part of it is lost without utilization. These by-products remain from the squeeze of tomato; is rich in protein, energy and crude fiber $(7,8)$. Wet tomato pulp can be further dried to approximately $900 \mathrm{~g} / \mathrm{kg} \mathrm{DM}$ and, because of its chemical composition, which possesses nutritional value, can provide the poultry industry with an alternative feedstuff (9).

The objective of this study was to economically evaluate substitution the corn with Dried Tomato Pomace (DTP) for mallard duck by study their effect on the productive and economic performance traits that included final body weight, feed conversion rate, feed efficiency, total costs, total returns and finally net returns. Also biochemical profiles of total proteins and lipids were measured for determine the effect of DTP on the quality of the meat for Mallard duck.

\section{Materials and methods}

This work was carried out during the period from January 2017 till March 2017.

A total number of 240, unsexed one - day old, Mallard ducklings were used in this study. All ducks were weighed individually and distributed randomly among 4 treatments each treatment include 60 ducks were nearly similar in initial average body weights.

\section{Data collection}

Rations were formulated to contain approximately the same crude protein level, and energy (kcal/ kg). Four treatments were used: - T1 (controlled), corn - soy diet fed for group (1). $\mathrm{T} 2,10 \%$ Tomato Pomace replaces corn fed for group (2). T3, 15\% Tomato Pomace replaces corn fed for group (3). T4, 20\% Tomato Pomace replaces corn fed for group (4). Four experimental starter diets (from 1day to 42 days) and finisher diets (from 42 day to76days) were fed to ducklings and chemical analysis of experimental diets (10)

\section{Growth performance measurements}

Through the experiment, the following measurements were recorded:

\section{Live body weight ( $L B W)$}

Ducks were weighted in each blocks every 7 days during experimental period. Total individual live weights in each blocks were divided by the number of ducks in the blocks to obtain the average live body weight.

\section{Feed intake}

Ducks in each treatment were provided with a weighed amount of feed every 1 week, the residual were obtained at the end of the 1 week of age and the amount consumed was calculated by the difference. The average amount of feed consumed per duck = amount of feed consumed per ducks / number of duck consuming feed.

\section{Feed conversion rate ( $F C R)$}

Feed conversion rate $=($ feed intake per kilograms in week / body weight gain per kilograms in week) (11).

\section{Feed efficiency (FE)}

The feed efficiency is weekly or for total experimental period and calculated as follow: Feed efficiency $=($ Gain in live body weight in this period / Feed intake in certain period) $(12,13)$.

\section{Blood parameters}

On a random basis, blood samples were collected from 5 ducks per group at slaughtering 
and lipid profiles including triglycerides (TG) (14), total cholesterol (TC), high density lipoprotein (HDL) (15), low density lipoprotein (LDL) (16) were determined. Also total plasma proteins (TP) (17), albumin (ALB) (18), globulin (GLB) (19), were determined calorimetrically using the commercial kits (ELITech SEEPPIM S.A.S. Zone industrielle - 61500 France).

\section{Economic analysis}

At the end of experiment, the following indices were calculated per each groups of duck: Total fixed costs (TFC), total costs (TC) $(15,20)$. Total return (NR), net profit (NP) and economic efficiency $(\mathrm{EE})(11,12,21,22,23$, $24,25,26)$.

\section{Statistical Analysis}

Data handling and statistical analysis was carried out at the Dept. of Animal Wealth Development, Faculty of Vet. Medicine, Zagazig University. Analysis was done using SPSS/PCT, (Statistical Package for Social Sciences version 22.0) (IBM Corp., Armonk, NY, USA) software Results were reported in means \pm SEM (Standard Error of Mean). The value of $\mathrm{P}<0.05$ was used to indicate statistical significance. The statistical method was ANOVA test (one way analysis of variance) to test the differences in productive and economic efficiency parameters of ducks according to different experimental diets. The Duncan multiple range test are also used $(27,28)$.

\section{Results}

\section{Growth performance}

The effects of different levels of dietary DTP on final body weight, Total feed intake, FCR and FE were showed in Table 3. And results showed that the final body weight was significant $(\mathrm{P}<0.05)$ where the highest in $\mathrm{T} 4$ and the lowest was in T1.also the total feed intake was significant $(P<0.05)$ different in different groups the highest was in T3. Meanwhile the feed efficiency and the feed conversion ratio are high with significant in $\mathrm{T} 1$ and $\mathrm{T} 3$ respectively.

\section{Biochemical analysis}

The different protein profiles are analyzed in table (4) where the total protein, globulin and $\mathrm{A} / \mathrm{G}$ ratio are non-significant at $(\mathrm{P}>0.05)$. Meanwhile the total albumin are high significant at $(\mathrm{P}<0.05)$ for different groups where the value are high in control groups (5.66) and in T2, T3 and T4 the values were 5.27, 5.36 and 5.45 respectively. Table 5 shows the analysis for different lipid profiles, the mean values for total cholesterol, high density lipoprotein (HDL), low density lipoprotein(LDL) and triglycerides all are significant at $(\mathrm{P}<0.05)$.

\section{Economical analysis}

The different economic measures are shown in table 6 that shown highly significant $(\mathrm{P}<$ 0.05 ) for total variable costs (LE/ duck), total costs (LE/ duck), total returns (LE/ duck) and net profit (LE/ duck) for different groups and shown that T4 is the highest in terms of net returns and control group (T1) is the lowest in that term of net returns. Also this table shown that total fixed costs (LE/ duck) are non-significant at $(\mathrm{P}>0.05)$ for all groups.

The efficiency measures for economic analysis are shown in table 7 that includes percent of total returns to total costs, percent of total returns to total variable costs, percent of net profit to the total variable costs and finally percent of net profit to the total costs. All are significant at (P $<0.05)$.

\section{Discussion}

Considering our main interest was to establish a bio-economic optimum for feed formulation with DTP that meet the nutritional requirements of mallard duck and maintain maximum performance with least cost as well.

\section{Growth Performance}

The final body weight was highest in T4 with significant effect that indicate that the high percent of DTP (20\%) results in increasing the body weight gain and this results are consistent with those of (4) who reported that DTP increase feed performance and final body weight. 
Table 1: Chemical composition (\%) of experimental diets used in the starter stage from 1 weeks

\begin{tabular}{|c|c|c|c|c|}
\hline \multirow[t]{2}{*}{ to 7 weeksItem $\%$} & \multicolumn{4}{|c|}{ Experimental diets for each $100 \mathrm{~kg}$ diet } \\
\hline & Control & $\begin{array}{c}10 \% \text { Tomato } \\
\text { pomace }\end{array}$ & $\begin{array}{c}15 \% \text { Tomato } \\
\text { pomace }\end{array}$ & $\begin{array}{l}20 \% \text { Tomato } \\
\text { pomace }\end{array}$ \\
\hline $\mathrm{ME}, \mathrm{Kcal} / \mathrm{Kg}$ & 2891 & 2890 & 2883 & 2872 \\
\hline $\mathrm{CP}, \%$ & 22.41 & 22.25 & 22.24 & 22.22 \\
\hline $\mathrm{EE}, \%$ & 4.38 & 4.64 & 4.76 & 4.90 \\
\hline $\mathrm{CF}, \%$ & 3.5 & 5.4 & 6.43 & 7.29 \\
\hline $\mathrm{Ca}, \%$ & 0.92 & 0.92 & 0.92 & 0.92 \\
\hline Lysine, \% & 1.13 & 1.12 & 1.11 & 1.11 \\
\hline Methoinine, \% & 0.4 & 0.4 & 0.4 & 0.4 \\
\hline Available ph.\% & 0.58 & 0.58 & 0.58 & 0.58 \\
\hline
\end{tabular}

ME: Meatabolizale Energy CP : Crude Protein CF: Crude Fiber Ca : Calcium

Table 2: Chemical composition (\%) of experimental diets used in the finisher stage from 7 weeks to 10 weeks

\begin{tabular}{lcccc}
\hline Item \% & \multicolumn{4}{c}{ Experimental diets for each $100 \mathrm{~kg}$ deit } \\
\cline { 2 - 5 } & Control & $\begin{array}{c}10 \% \text { Tomato } \\
\text { pomace }\end{array}$ & $\begin{array}{c}15 \% \text { Tomato } \\
\text { pomace }\end{array}$ & $\begin{array}{c}20 \% \text { Tomato } \\
\text { pomace }\end{array}$ \\
$\mathrm{ME}, \mathrm{Kcal} / \mathrm{Kg}$ & 3000 & 2994 & 2987 & 2981 \\
$\mathrm{CP}, \%$ & 19.83 & 19.76 & 19.74 & 19.71 \\
$\mathrm{EE}, \%$ & 6.8 & 7.07 & 7.21 & 7.34 \\
$\mathrm{CF}, \%$ & 3.37 & 5.37 & 6.37 & 7.43 \\
$\mathrm{Ca}, \%$ & 0.95 & 0.95 & 0.95 & 0.95 \\
Lysine, \% & 1.18 & 1.17 & 1.16 & 1.15 \\
Methoinine, \% & 0.50 & 0.49 & 0.48 & 0.48 \\
\hline Available ph.\% & 0.45 & 0.45 & 0.45 & 0.45 \\
\hline
\end{tabular}

ME: Meatabolizale Energy CP : Crude Protein CF: Crude Fiber Ca : Calcium

Table 3: Economic parameters of Mallard duck performance that affected by dietary treatments

\begin{tabular}{lcccc}
\hline Items & \multicolumn{3}{c}{ Different treatments that supplied with dried tomato pomace } \\
\cline { 2 - 5 } & Treatment 1 (T1) & Treatment 2(T2) & Treatment 3 (T3) & Treatment 4 (T4) \\
Number of ducks & 60 & 60 & 60 & 60 \\
$\begin{array}{l}\text { Initial body } \\
\text { weight (g) }\end{array}$ & $57.53 \pm 0.18^{\mathrm{a}}$ & $57.37 \pm 0.18^{\mathrm{a}}$ & $57.46 \pm 0.20^{\mathrm{a}}$ & $57.36 \pm 0.19^{\mathrm{a}}$ \\
$\begin{array}{l}\text { Final body weight } \\
\text { g) }\end{array}$ & $4020.93 \pm 5.78^{\mathrm{c}}$ & $4108.11 \pm 8.42^{\mathrm{b}}$ & $4146.68 \pm 3.44^{\mathrm{a}}$ & $4154.03 \pm 3.03^{\mathrm{a}}$ \\
$\begin{array}{l}\text { Total Feed intake } \\
\text { g) }\end{array}$ & $8082.73 \pm 6.18^{\mathrm{c}}$ & $8513.60 \pm 54.17^{\mathrm{b}}$ & $8786 . .27 \pm 40.84^{\mathrm{a}}$ & $8716.85 \pm 39.18^{\mathrm{a}}$ \\
$\begin{array}{l}\text { Feed Conversion } \\
\text { rate (FCR) }\end{array}$ & $2.01 \pm 0.003^{\mathrm{c}}$ & $2.07 \pm 0.10^{\mathrm{b}}$ & $2.11 \pm 0.009^{\mathrm{a}}$ & $2.09 \pm 0.009^{\mathrm{a}}$ \\
\hline $\begin{array}{l}\text { Feed Efficiency } \\
(\text { FE) }\end{array}$ & $0.49 \pm 0.008^{\mathrm{a}}$ & $0.48 \pm 0.002^{\mathrm{b}}$ & $0.47 \pm 0.002^{\mathrm{c}}$ & $0.47 \pm 0.002^{\mathrm{c}}$ \\
\hline
\end{tabular}

Means within the same row in each category carrying different litters are significant at $(\mathrm{P} \leq 0.05)$ 
Table 4: Effect of experimental diets on protein profiles of Mallard ducks (Mean $\pm \mathrm{SE}$ )

\begin{tabular}{|c|c|c|c|c|c|}
\hline Groups & No. & Treatment 1 (T1) & $\begin{array}{r}\text { Treatment } 2 \\
\text { (T2) }\end{array}$ & $\begin{array}{r}\text { Treatment } 3 \\
\text { (T3) }\end{array}$ & Treatment 4 (T4) \\
\hline $\begin{array}{r}\text { Total } \\
\text { protein } \\
(\mathrm{g} / \mathrm{dl})\end{array}$ & 5 & $5.66 \pm 0.05^{\mathrm{a}}$ & $5.27 \pm 0.03^{\mathrm{a}}$ & $5.36 \pm 0.07^{\mathrm{a}}$ & $5.45 \pm 0.01^{\mathrm{a}}$ \\
\hline $\begin{array}{r}\text { Albumin } \\
(\mathrm{g} / \mathrm{dl})\end{array}$ & 5 & $2.49 \pm 0.03^{\mathrm{a}}$ & $2.16 \pm 0.03^{b}$ & $2.17 \pm 0.05^{\mathrm{b}}$ & $2.27 \pm 0.05^{\mathrm{b}}$ \\
\hline $\begin{array}{r}\text { Globulin } \\
(\mathrm{g} / \mathrm{dl})\end{array}$ & 5 & $3.17 \pm 0.07^{\mathrm{a}}$ & $3.10 \pm 0.04^{\mathrm{a}}$ & $3.19 \pm 0.03^{\mathrm{a}}$ & $3.18 \pm 0.06^{\mathrm{a}}$ \\
\hline $\mathrm{A} / \mathrm{G}$ ratio & 5 & $0.78 \pm 0.01^{\mathrm{a}}$ & $0.69 \pm 0.01^{\mathrm{a}}$ & $0.68 \pm 0.02^{\mathrm{a}}$ & $0.71 \pm 0.01^{\mathrm{a}}$ \\
\hline \multicolumn{6}{|c|}{ Means carrying different superscripts in the same row are sig. different at $(\mathrm{P}<0.05)$} \\
\hline Groups & No. & Treatment 1 (T1) & $\begin{array}{l}\text { Treatment } 2 \\
\text { (T2) }\end{array}$ & $\begin{array}{l}\text { Treatment } 3 \\
\text { (T3) }\end{array}$ & Treatment 4 (T4) \\
\hline $\begin{array}{l}\text { Total } \\
\text { cholesterol } \\
(\mathrm{mg} / \mathrm{dl})\end{array}$ & 5 & $196.6 \pm 1.36^{\mathrm{a}}$ & $172.2 \pm 1.04^{\mathrm{b}}$ & $172.9 \pm 0.81^{\mathrm{b}}$ & $173.6 \pm 0.82^{b}$ \\
\hline $\begin{array}{l}\text { LDL- } \\
\text { cholesterol } \\
(\mathrm{mg} / \mathrm{dl})\end{array}$ & 5 & $77.21 \pm 1.04^{\mathrm{b}}$ & $77.16 \pm 0.43^{b}$ & $77.76 \pm 1.07^{\mathrm{a}}$ & $77.85 \pm 0.87^{\mathrm{a}}$ \\
\hline $\begin{array}{l}\text { HDL- } \\
\text { cholesterol } \\
(\mathrm{mg} / \mathrm{dl})\end{array}$ & 5 & $83.52 \pm 0.90^{\mathrm{a}}$ & $66.93 \pm 2.91^{\mathrm{b}}$ & $66.00 \pm 0.79^{b}$ & $67.65 \pm 0.75^{\mathrm{b}}$ \\
\hline $\begin{array}{l}\text { Triglycerides } \\
(\mathrm{mg} / \mathrm{dl})\end{array}$ & 5 & $218.69 \pm 2.29^{\mathrm{a}}$ & $200.08 \pm 3.15^{b}$ & $198.92 \pm 1.61^{\mathrm{b}}$ & $201.84 \pm 1.52^{\mathrm{b}}$ \\
\hline
\end{tabular}

Means carrying different superscripts in the same row are sig. different at $(\mathrm{P}<0.05)$

Table 6: Economic parameters of duck performance that affected by dietary treatments

\begin{tabular}{|c|c|c|c|c|}
\hline Items & & Different treatment & hat supplied with $\mathrm{c}$ & ed tomato pomace \\
\hline Number of ducks & $\begin{array}{l}\text { Treatment } 1(\mathrm{~T} 1) \\
60\end{array}$ & $\begin{array}{c}\text { Treatment } 2(\mathrm{~T} 2) \\
60\end{array}$ & $\begin{array}{c}\text { Treatment } 3(\mathrm{~T} 3) \\
60\end{array}$ & $\begin{array}{c}\text { Treatment } 4(\mathrm{~T} 4) \\
60\end{array}$ \\
\hline $\begin{array}{l}\text { Total Variable } \\
\text { cost (LE/Duck) }\end{array}$ & $70.04 \pm 0.15^{\mathrm{a}}$ & $67.78 \pm 0.21^{\mathrm{b}}$ & $67.04 \pm 0.14^{\mathrm{c}}$ & $66.06 \pm 0.15^{\mathrm{c}}$ \\
\hline $\begin{array}{l}\text { Total Fixed cost } \\
\text { (LE/Duck) }\end{array}$ & $11.65 \pm 0.11^{\mathrm{a}}$ & $11.65 \pm 0.12^{\mathrm{a}}$ & $11.64 \pm 0.11^{\mathrm{a}}$ & $11.51 \pm 0.10^{\mathrm{a}}$ \\
\hline $\begin{array}{l}\text { Total cost } \\
\text { (LE/Duck) }\end{array}$ & $81.69 \pm 0.19^{\mathrm{a}}$ & $79.43 \pm 0.24^{\mathrm{b}}$ & $78.69 \pm 0.18^{c}$ & $77.57 \pm 0.17^{c}$ \\
\hline $\begin{array}{l}\text { Total Returns } \\
\text { (LE/Duck) }\end{array}$ & $88.46 \pm 0.12^{\mathrm{c}}$ & $90.37 \pm 0.18^{b}$ & $91.22 \pm 0.07^{\mathrm{a}}$ & $91.38 \pm 0.06^{\mathrm{a}}$ \\
\hline $\begin{array}{l}\text { Net Profit } \\
\text { (LE/Duck) }\end{array}$ & $6.76 \pm 0.20^{c}$ & $10.94 \pm 0.37^{\mathrm{b}}$ & $12.53 \pm 0.20^{\mathrm{a}}$ & $13.81 \pm 0.20^{\mathrm{a}}$ \\
\hline
\end{tabular}

Means within the same row in each category carrying different litters are significant at $(\mathrm{P} \leq 0.05)$ 
Table 7: Economic efficiency of Mallard duck performance that affected by dietary treatments

\begin{tabular}{|c|c|c|c|c|}
\hline \multirow{2}{*}{ Items } & \multicolumn{4}{|c|}{ Different treatments that supplied with dried tomato pomace } \\
\hline & $\begin{array}{c}\text { Treatment } 1 \\
\text { (T1) }\end{array}$ & $\begin{array}{l}\text { Treatment } 2 \\
\text { (T2) }\end{array}$ & $\begin{array}{c}\text { Treatment } 3 \\
\text { (T3) }\end{array}$ & $\begin{array}{c}\text { Treatment } 4 \\
\text { (T4) }\end{array}$ \\
\hline Number of ducks & 60 & 60 & 60 & 60 \\
\hline $\begin{array}{l}\text { Total Return / total } \\
\text { cost }(\%)\end{array}$ & $1.08 \pm 0.002^{\mathrm{c}}$ & $1.13 \pm 0.005^{\mathrm{b}}$ & $1.15 \pm 0.002^{\mathrm{a}}$ & $1.17 \pm 0.002^{\mathrm{a}}$ \\
\hline $\begin{array}{l}\text { Total Return / total } \\
\text { variable cost }(\%)\end{array}$ & $1.26 \pm 0.002^{\mathrm{c}}$ & $1.33 \pm 0.006^{\mathrm{b}}$ & $1.36 \pm 0.003^{\mathrm{a}}$ & $1.37 \pm 0.003^{\mathrm{a}}$ \\
\hline $\begin{array}{l}\text { Net Return / Total } \\
\text { variable cost }(\%)\end{array}$ & $0.09 \pm 0.003^{c}$ & $0.16 \pm 0.005^{\mathrm{b}}$ & $0.18 \pm 0.003^{\mathrm{a}}$ & $0.20 \pm 0.003^{\mathrm{a}}$ \\
\hline $\begin{array}{l}\text { Net Returns / Total } \\
\text { cost }(\%)\end{array}$ & $0.08 \pm 0.002^{c}$ & $0.13 \pm 0.005^{\mathrm{b}}$ & $0.15 \pm 0.002^{\mathrm{a}}$ & $0.17 \pm 0.002^{\mathrm{a}}$ \\
\hline
\end{tabular}

Means within the same row in each category carrying different litters are significant at $(\mathrm{P} \leq 0.05)$

The total feed intake (g/duck), feed conversion ratio and feed efficiency are the highest in T4 and T3 that results are agreement with (7) who found that dried tomato pomace can be used in broiler chicken diets up to $20 \%$. However, in general it seems dried tomato pomace can be used in poultry diets as a feed ingredient any level and results in increasing total feed intake, FE and FCR. These results were in contrary with (29) who reported that increased TP level $(10,20 \%)$ in both starter and finisher broiler chicken diets resulted lower live weight ( $\mathrm{P}<0.01)$. However there was no significant difference between control and 5\% DTP supplemented diet groups.

\section{Biochemical analysis}

The total protein, globulin and $\mathrm{A} / \mathrm{G}$ ratio are non-significant at $(\mathrm{P}>0.05)$. The observed result was agreed with (30) who recorded that total protein, globulin and albumin: globulin ratio levels of broilers not affected by different levels of DTP.

Table 5 shows the analysis for different lipid profiles, the result revealed significant $(\mathrm{P}<0.05)$ decrease in total cholesterol, triglycerides, HDL and LDL levels. The total cholesterol of control group was $196.6 \mathrm{mg} / \mathrm{dl}$ while that of the groups fed diet contained 5\%, 10\% and 20\% DTP were $172.2,172.9$, and $173.6 \mathrm{mg} / \mathrm{dl}$ respectively. The triglycerides of control group was $281.69 \mathrm{mg} / \mathrm{dl}$ while that of the groups fed diet contained 5\%, $10 \%$ and $20 \%$ DTP were 200.08, 198.92, and $201.84 \mathrm{mg} / \mathrm{dl}$ respectively. Also the HD of control group was $83.52 \mathrm{mg} / \mathrm{dl}$ and that T2, T3 and T4 were $66.93,66.00$ and $67.65 \mathrm{mg} / \mathrm{dl}$ respectively. The LDL level of control group was $77.21 \mathrm{mg} / \mathrm{dl}$ and for T2, T3 and T4 were 77.16, 77.76 and $77.85 \mathrm{mg} / \mathrm{dl}$ respectively

The observed result was agreed with (30) who recorded that the serum cholesterol content, LDL and HDL of poultry fed on diet contained 8, 16\% DTP were lower as compared with other groups $(\mathrm{P}<0.05)$. In the same line (31) reported that tocopherols and tocotrienols in DTP lowers serum cholesterol by supperessing the posttranscriptional action of 3-hydroxy3-methylglutaryl coenzyme A (HMG-CoA)reductase, the rate-limiting enzyme in the mevalonate pathway of endogenous cholesterol synthesis by the liver

\section{Economical analysis}

Table (6): showed non significant difference $(\mathrm{P}>0.05)$ among all groups for the total fixed cost where at the control groups it was 11.65 
LE/duck and for T2,T3 and T4 total fixed costs were $11.65,11.64$ and $11.51 \mathrm{LE} /$ duck. The total variable costs are significant difference $(\mathrm{P}<$ 0.05 ) among all groups where the large total variable costs was at T1 (70.04 LE/duck) and the lowest one was at T4 (66.06LE/duck).

Also in Table (6): showed significant difference $(\mathrm{P}<0.05)$ among all groups for the total returns where at the control groups it was 88.46 LE/duck and for T2,T3 and T4 the total returns were 90.37 91.22, and 91.38 LE/duck respectively. This results indicates the significance using Tomato pomace at $20 \%$ for the group four more than $10 \%$ and $15 \%$. And the highly total returns in this group may be due to the high final growth weight in this group.

Table (6): showed significant difference $(\mathrm{P}<$ 0.05 ) among all groups for the net profit where at the control groups it was $6.76 \mathrm{LE} /$ duck and for $\mathrm{T} 2, \mathrm{~T} 3$ and $\mathrm{T} 4$ the for the net profit were $10.94,12.53$, and $13.81 \mathrm{LE} /$ duck respectively. This results indicates the significance difference among all groups in the net profit and as showed the higher body weight gain in $\mathrm{T} 4$ are due to the high feed intake and consequently high total returns and finally higher net profit.

Table (5): showed significant difference $(\mathrm{P}<0.05)$ between all groups for the different economic efficiency measures. The percent of total returns to the total cost for the control groups it was 1.08 and for T2,T3 and T4 were $1.13,1.15$ and 1.17 respectively.

Meanwhile The percent of total returns to the total variable cost for $\mathrm{T} 4$ groups was 1.37 and for $\mathrm{T} 1, \mathrm{~T} 2$, and $\mathrm{T} 3$ were $1.26,1.33$ and 1.36 respectively. Also in table (5), The percent of net returns to the total cost is higher in $\mathrm{T} 4$ group ( 0.17 ) and for T1, T2 , and T3 were 0.08 , 0.13 and 0.15 respectively. These economic results agree with $(32,20)$.

\section{Conclusion}

Using of Tomato pomace as a percentage of corn has no side effect on the final growth weight of the mallard ducks and through this research work the $20 \%$ is more economic than $15 \%$ and $10 \%$ so we concluded that using the tomato pomace with percentage of $20 \%$ of the corn to the ration of the mallard duck and suggested that new research are needed to study the effect of percentage more than $20 \%$ as percentage of corn in ration of mallard duck.

\section{Conflict of interest}

The authors declare that they have no conflict of interest.

\section{References}

1. Ahmed A. A comparative study on the effect of some growth promoters in chickens. Ph.D. Thesis, Pharmacology Dept., Fac. Vet. med., Zagazig University Egypt 2014.

2. Ayhan V, Aktan S. Using Possibilities of Dried Tomato Pomace in Broiler Chicken Diets. Hayvansal Uretim 2004; 45(1):19-22.

3. Kannan D, Viswanathan K, Mohan B. The effect of feeding Virginiamycin and Lactobacillus sporogenes on broiler production performance characters. Tamilnadu Journal of Veterinary and Animal Sciences 2007; 3 (2): $106-8$.

4. Nobakht A, Safamehr A. The effect of inclusion different levels of dried tomato pomace in laying hens diets] on performance and plasma and egg yolk cholesterol content. J.of Anim. \& Vet.Advances 2007; 6(9):1101-6.

5. Ben-Gera I, Kramer, A The utilization of food industries wastes. Advanced Food Research 1969; 17: 77-135.

6. Persia M, Parsons C, Schang M, Azcona J. Nutritional evaluation of dried tomato seeds. Poult. Science 2003; 82: 141-6.

7. El-Hassan M. Effect of some agricultural industrial byproducts on the performance of broiler chicks. Ph.D. Thesis Fac Agric. Zagazig, Univ. Egypt.1999.

8. Soliman A, Abd El-Baset A, Amany A. Utilization of tomato by-products in growing rabbit diets. J. Agric. Sci. Mansoura University 2005; 8: 4469-83.

9. Jafari M, Pirmohammadi R, Bampidis V. The use of dried] tomato pulp in diets of laying hens. Int. J. Poult. Sci. 2006; 5: 618-22.

10. National Research C. Nutrient requirements of domestic animal (Poultry) 4th edition Nat. Acad. Sci. Washinton. D.C.12 1994.

11. Omar M. Economic and productive efficiency of poultry farms in relation to veterinary inputs. M.V.Sc. Thesis, Fac. Vet. Med., Zagazig University 2003. 
12. Omar M. Economic study on the productive and reproductive efficiency of dairy farms in relation to veterinary management. Ph.D. faculty of Veterinary Medicine Zagazig University 2009.

13. Rosegrant M, Msangi C, Ringler T, Sulser T, Zhu S. International Model for Policy Analysis of Agricultural Commodities and Trade (IMPACT) Model description. Washington, D.C. International Food Policy Research Institute 2008.

14. Buccolo, G. Quantitative determination of serum triglycerides by use of enzymes. Clin Chem 1973; 19 (5): 476-82

15. Naito H, Kaplan A. High density lipoprotein (HDL) Cholesterol. Clin Chem. Toronto. Princeton 1984; 1207-13.

16. Saleh A A, Amber K, El-Magd M A, Atta M S, Mohammed A A, Ragab M M, Abd El-Kader H. Integrative effects of feeding Aspergillus awamori and fructooligosaccharide on growth performance and digestibility in broilers: promotion muscle protein metabolism, Biomed Res Int 2014; 2014: 946859.

17. Abdelhady D H, El-Magd M A, Elbialy Z I, Saleh A A. Bromuconazole-induced hepatotoxicity is accompanied by upregulation of PXR/CYP3A1 and downregulation of CAR/CYP2B1 gene expression, Toxicol Mech Methods 2017; 27(7): 544-50.

18. Doumas B, Watson W, Biggs H, Albumin standards and the measurement of serum albumin with bromocresol green Clin. Chem.Acta 1973; 31:83-7.

19. Doumas B, Biggs H, Determination of serum globulin standard methods of clinical chemistry Edited by cooper, New York, Academic press 1972; (7).

20. Nasser A. Economic Evaluation Of Some Unconventional Rations in Duck Farms Master degree thesis . Faculty of Veterinary Medicine .Zagazig University 2014.

21. Atallah S. Effect of cattle diseases on reproductive, productive and economic efficiency of dairy farms. Minufiya Vet. J. 2004; 99-114.
22. Atallah S. Economic and productive efficiency of veterinary management in dairy farms. Ph.D. Degree, Animal Husbandry Department, Faculty of Veterinary Medicine Alexandria University 1997.

23. El-Tahawy A. Cattle diseases and their effects on economic and productive efficiency of dairy farms. Ph.D. Faculty of Veterinary Medicine, Alexandria University 2007.

24. Gilson W, Analysis of mastitis costs. Annual report. UGA Animal and Dairy Science 1995; 182185.

25. Lotfollahian H, Hosseini S. Evaluation of metabolizable energy values of some feeding stuffs Pak.,J.Biol. Sci 2007; 10: 995-7.

26. Lundholm M . Cost-benefit analysis and the marginal cost of public funds. Department of Economics.Stockholm University 2005.

27. Cooper W, Seiford L, Zhu J, Hand book on Data Envelopment Analysis Springer, Kluwer Academic 2004.

28. Duncan D. Multiple range and multiple F. tests. Biometrics 1955; (11): 1-42.

29. Squires M, Naber E, Toella V. The effect of heat, water, acid and alkali treatment of tomato cannary waste on growth, metabolizable energy value and nitorgen utilization of broiler chicks. Poult. Sci., 1992; 71: 522--9.

30. Rahmatnejad E, Bojarpour, A, Mirzadeh, K, Chaji A, Ashayerizadeh O. The effect of different levels of dried tomato pomace on broiler chicken haematological indices. Journal of Animal and Veterinary Advances 2009; 8(10): 1989-92

31. Song-Hae B, Sung-Heui L, Yong-Bok P, KiHwan B, Kwang-Hee S, Tae-Sook J, Myung-Sook C. Plasma and hepatic cholesterol and hepatic activities of 3-hydroxy-3-methyl-glutaryl-CoA lower in rats fed citrus peel extract or mixture of citrus bioflavonoids J.Nutr. 1999; 129: 1182-5.

32. Mohamed A, Abdel-Hamid T. Economic Evaluation of using Dried Tomato Pomace (DTP) for Ducks. Proc. of the 6th Animal Wealth Research Conf. in the Middle East \& North Africa MENAJAS) ISSN online 2013; 20: 2356-6302. 